\title{
PerCursos
}

\section{Enfrentando distopias contemporâneas: por uma disputa contra-hegemônica}

\section{Resumo}

Tratamos neste artigo sobre as possiblidades de engajamento políticocultural no contexto pandêmico da Covid-19, as reais perspectivas de articulações sociais no âmbito de disputas por políticas que não atendam somente os aspectos da sobrevivência imediata, mas também que visem resoluções no campo democrático que nos levem a uma transformação qualitativa de nossa sociedade. Encontramo-nos diante do sentimento, descrito por Ernst Bloch, de uma "falta de algo" que nos incita a buscar outro modo de vida, os sentidos utópicos que nos levam à efetiva luta. Assim, aqui buscamos elucidar os preceitos das estruturas - tais como os lobbies do setor de tecnologia e seus conglomerados, os avanços antidemocráticos, instrumentalizados pela Lawfare, autoritarismo e anticonstitucionalismo do governo federal brasileiro, os ataques aos trabalhadores da educação e à própria disputa no setor educacional como campo de controle - , que podem nos encaminhar para o rompimento das distopias que cercam o cotidiano da classe trabalhadora, em especial a realidade educacional brasileira e seus desafios e gargalos que se exponenciam com a pandemia da Covid-19.

Palavras-chave: Utopias. Distopias. Neoliberalismo. Educação. Pandemia da Covid-19. Ideologia.
Danielle do Nascimento Rezera

Doutoranda em Educação pela

Universidade Federal de São

Paulo - UNIFESP. Professora do

Centro Universitário Sumaré e

Educadora social.

Brasil

daniellerezera@yahoo.com.br

\section{Agenor Bevilacqua Sobrinho}

Doutor em Artes Cênicas pelo

CAC/ECA-USP. Professor

universitário, dramaturgo, editor

e escritor. Pesquisador do

Grupo de Pesquisa "Estudos histórico-críticos e dialéticos de teatro estadunidense e brasileiro" (CNPq). Brasil ciafagulha@gmail.com

\footnotetext{
Para citar este artigo:

REZERA, Danielle do Nascimento; BEVILACQUA SOBRINHO, Agenor. Enfrentando distopias contemporâneas: por uma disputa contra-hegemônica. PerCursos, Florianópolis, v. 21, n.47, p. 04 - 30 , set./dez. 2020.
}

DOI: $10.5965 / 1984724621472020004$

http://dx.doi.org/10.5965/1984724621472020004 


\title{
Facing contemporary dystopias: for a counter- hegemonic dispute
}

\begin{abstract}
In this article, we discuss the possibilities of politicalcultural engagement in the pandemic context of Covid19 , the real perspectives of social articulations in the context of disputes over policies that do address not only the aspects of immediate survival but also that aim at resolutions in the democratic field, leading us to a qualitative transformation of our society. We find ourselves facing the feeling, described by Ernst Bloch, of a "lack of something" that encourages us to look for another way of life, the utopian senses that lead us to the effective struggle. Thus, here we seek to elucidate the precepts of the structures - such as the lobbies of the technology sector and its conglomerates, the antidemocratic advances, instrumentalized by Lawfare, authoritarianism, and anti-constitutionalism of the Brazilian federal government, the attacks on education workers and the very dispute in the educational sector as a control field $\neg-$, which can lead us to break the dystopias that surround the daily life of the working class, especially the Brazilian educational reality and its challenges and bottlenecks that are exponential with the Covid-19 pandemic.
\end{abstract}

Keywords: Utopias. Dystopias. Neoliberalism. Education. Covid-19 Pandemic. Ideology. 


\section{Introdução}

A utopia é sinônimo de uma variedade de ensejos de mudanças significativas em relação às estruturas de convívio, de sociabilidade, modos de sobrevivência, melhores condições econômicas e de saúde física e emocional da humanidade. Contudo, se não cuidada e acuradamente ancorada na realidade histórica e nas concretudes dos campos políticos e culturais, bem como suas questões objetivas e subjetivas, a utopia em si pode tornar-se inviável, mesmo parcialmente.

Em termos etimológicos: Utopia, do latim tardio utopia; pelo grego: ou (não) + tópos (lugar). Utopia é um termo que designa realidades "fictícias" contrastivas em relação ao presente de determinada sociedade (Thomas More); as expressões quiméricas de mudanças sem verificar o chão histórico e a correlação de forças entre classes sociais para seu processamento (crítica de Marx e Engels aos socialistas utópicos); mas também as tentativas de elaborar quaisquer ideais de transformações profundas nas condições de vida, em suas diferentes dimensões. Podendo assumir características evasivas ou catalisar e impulsionar forças sócio-históricas no sentido de viabilizar correções de envergadura e inovações profundas. Ademais, a utopia não pode aprisionar com uma descrição exata o que deveria ser a sociedade do futuro, pois isso engessaria as possibilidades e dinâmicas históricas (BENJAMIN, 1987; MARX, 1978).

Distopia, em geral, designa lugares ou circunstâncias “imaginárias” em que reinam a opressão, distintas formas de privação e desesperança; situações próprias de sociedades totalitárias.

Bauman (2017), em entrevista à revista Cult, sobre sua obra Tempos Líquidos, faz alusão à obra de William Morris (A Dream of John Ball) para trazer elementos da constituição da utopia como movimento de luta. Ele indica que na obra de Morris há elementos dos "seres humanos como tais, que lutam por uma 'coisa que não é". Esse "não" é tratado por Ernst Bloch, de acordo com Bauman, como 'a falta de algo e também o fugir do que falta'. Para o filósofo polonês, as utopias "foram todas as tentativas de enunciar e descrever em detalhes a coisa para a qual a próxima luta seria dirigida". Ele distingue duas formas de utopias: a primeira seria a utopia Modelo (que se estrutura em 
padrões e projeta o tempo das possibilidades) e a segunda, que ele denomina iconoclasta (esta não possui a intenção de projetar algo). Para Bauman:

a principal causa do utopismo iconoclasta é a possibilidade de uma alternativa à realidade social, apesar de o seu desenho estar pouco desenvolvido. As utopias iconoclastas, presumo, são aberta ou tacitamente o caminho para uma sociedade superior, não se conduzem por meio de desenhos ou conselhos, mas sim por meio da reflexão crítica sobre práticas e crenças existentes de forma a — para recordar uma ideia de Bloch - explicitar que 'uma coisa está faltando' e assim 'inspirar a unidade para a sua criação e recuperação' (BAUMAN, 2017, sem paginação).

Em sua famosa obra Princípio Esperança, Ernst Bloch (2005) entende por utopia a necessária vontade dos indivíduos ou conjunto deles de manifestar a elaboração já organizada internamente sobre a realidade presente. A utopia é a necessidade de ativar um processo mais amplo no seio social, que leva ao fomento de rupturas. Seria como a necessidade de fagulha para que haja a fogueira. A compreensão do filósofo é a de que, a partir das manifestações para o rompimento do status quo e a busca por uma nova realidade, há também um rearranjo imperioso para que seja efetivo tal intento pois, para ele, a vontade e a atuação devem ser coletivas por uma questão obviamente ética e certamente assertiva.

A utopia que visa transformar para melhor o mundo em que se vive é uma vontade crítica, parte de uma revisão de uma realidade e, se crítica, é uma ação política de contestação e, se posta em prática, deve ser no campo político. A concepção blochiana se dá na lógica de um marxismo humanista, e vê na obra de Marx e Engels a percepção cada vez mais acurada de uma vontade de transformação do homem, como sujeito carregado de questões objetivas, mas subjetivas também, capaz de emancipar-se, de desalienar-se do que o impede de desenvolver-se como indivíduo e coletivo. Na obra de Bloch, esperança é sinônimo de utopia crítica, fundamentada na realidade e na concretude de sua transformação qualitativa. Para o autor, é no marxismo que se encontram os efetivos meios para as possibilidades futuras de quaisquer que sejam os sonhos de rompimento 
das desigualdades, não idealista ou factual em si, mas as bases históricas concretas e sua ampla análise fortalecerão os que vão além dos sonhos.

A pandemia do Covid-19 trouxe ao imaginário uma gama de reflexões sobre o futuro, sobre as possibilidades de um porvir próximo que tende a transformar-se de modo profundo. Imediatamente aos primeiros sinais de isolamento mundial, alguns estudiosos (CASTELLS, 2020; SANTOS, 2020; ŽlŽEK, 2020) partiram da premissa de que todos estávamos diante do mesmo perigo, assim ficaríamos sob as mesmas condições de buscar soluções em comum, próximos de um necessário modo comunista de viver; pela situação e as contingências gerais, pela capacidade tecnológica de aproximação de pessoas no mundo todo, talvez, pudéssemos fazer dar certo. No entanto, no ínterim do avanço da pandemia, entendemos que grupos dirigentes atuaram rapidamente para fazer deste momento o ensaio de pretensões já explicitadas e articuladas anteriormente. Então, de maneira abrupta, aquela visão onírica de que haveria disposição de parte considerável da sociedade para soluções positivas foi alterada para um estado de inquietudes, violações de direitos, caos e uma queda à realidade muito mais dura do que se esperava. Inclusive, em alguns casos, passou-se direto para um futuro sem termos percorrido processos que nos preparassem para isso, tais como a obrigatoriedade de ensino remoto no Brasil sem os aparatos tecnológicos e a democracia digital que, no nosso entendimento, são base para tais intentos atuais no cenário educacional.

E não só pelo vírus em si, mas pelo que se produz social e economicamente a partir dele, como resume a escritora e ativista Naomi Klein, em sua cobertura sobre o desenvolvimento de tecnologias para o mundo pós-pandemia, da fundação Bill Gates.

Demorou algum tempo para ela se formar, mas algo parecido com uma Doutrina de Choque da Pandemia está começando a aparecer. Chamo de 'Screen New Deal'. Muito mais high-tech do que qualquer coisa que vimos nos desastres anteriores, o futuro que está surgindo à medida que os cadáveres ainda se acumulam está tratando nossas últimas semanas de isolamento não como uma necessidade dolorosa para salvar vidas, mas como um laboratório vivo para um futuro permanente - e altamente lucrativo — sem contato físico (KLEIN, 2020, sem paginação). 
Sabemos que os interesses concretos e contraditórios exprimem, através de suas ideias, as condições materiais para sua efetivação, e o entendimento de tais interesses tem capacidade de nos transportar para a realidade histórica da formação deles e da complexidade entre as ideias e o mundo real (MARX; ENGELS, 2007). Contudo, nem toda sociedade compreende a totalidade das determinações sociais e as múltiplas leituras dos vastos grupos que compõem seu ethos social.

Partindo desse pensamento, nos deparamos com realidades singulares, ideologicamente díspares e conflitivas ideias nos campos identitários, principalmente. Consideramos a partir de Kergoat (2012, apud HIRATA, 2014) que as relações sociais fundamentais (sexo, classe, raça), com sua complexidade e dinâmica, precisam ser evidenciadas. Assim, a categoria de consubstancialidade amplia o par gênero-raça, deixando a dimensão classe social em um plano mais visível (HIRATA, 2014, p. 65-66).

Porém o sistema de ódio, extrema violência, de exclusão dos meios de produção, assim como do direito à vida política no que tange aos campos decisórios do poder, exigem respostas organizadas e contundentes que não desconsiderem a dominação de classe no capitalismo. Nas estruturas sociais acompanha-se maior grau de violência por etnia, por sexo e por região e, com a crise sanitária exposta e ampliada durante esse período pandêmico, temos um aflorado ambiente de vicissitudes ainda mais reveladas e questionadas.

Para Žižek (2020), apesar de estarmos no mesmo barco pandêmico, já vínhamos num emaranhado processo de interconexão mundial, o que favoreceu a disseminação do vírus; a crise social pré-coronavírus tornou-se também, ela própria, vírus, contaminando a ideia de sociedade ajustada, de sociedade democrática, entre outras linguagens, nomenclaturas e retóricas que escamoteavam o caos social.

Entretanto, observamos que o "mesmo barco" tem divisões de classe, estamentais e outras, as quais determinam como serão afetados diferentemente os privilegiados, com suas inúmeras camadas protetivas político-econômicas-sanitárias etc., e os vulneráveis, desprovidos e jogados à própria sorte. No caso brasileiro, estes se 
encontram em circunstâncias em que se têm gerado fenômenos de inovação e fortalecimento de laços de solidariedade, com iniciativas de doação de 600 toneladas de alimentos pelo MST-Movimento dos Trabalhadores Sem Terra a famílias mais pobres (SUDRÉ, 2020), como também ações comunitárias e diversas redes internas de auxílio, ou, em distintos lugares, ocorre o recrudescimento de situações por si já exasperantes, todas tendo de lidar com a ausência da atuação do Estado, em decorrência dos cortes de verbas públicas draconianos efetuados pelo neoliberalismo conduzido por Paulo Guedes e sua equipe.

Logo se entendeu que o fatalismo não seria solução para o momento, justamente pela complexa e já atuante variedade de redes que atuam no campo civil em prol de realidades mais justas. Redes de solidariedade se formaram ou se fortaleceram no intuito de atender demandas urgentes, orientar, cuidar e incentivar novos hábitos econômicos, alimentares, higiênicos e políticos; foram questões que emergiram como lava em vulcão, indicando que, além de questionar as ações de governos, diversos grupos estavam mesmo interessados em ampliar redes e vínculos sociais capazes de transformar o cotidiano e a vida das pessoas, como temos visto no Brasil (MST, 2020; PERES, 2020).

Majoritariamente, os governos de diversos países, tais como Espanha, França e Argentina, tomaram atitudes urgentes de isolamento, alocação de recursos na saúde e de renda para seus cidadãos; isso se explica pelo estado de emergência sanitária, que poderia causar a mortandade de milhões de pessoas e, também, pela emergência da democratização política. Para Badiou, a epidemia apresenta uma complexidade intrigante aos Estados; pelo fato de ser sempre um ponto de articulação entre as determinações naturais e sociais, gera, portanto, tensão. "E sua análise completa é transversal, é preciso compreender os pontos em que as duas determinações se interceptam e tirar conclusões" (BADIOU, 2020, p. 37).

Compreende o autor que, no contexto da pandemia da Covid-19, os Estados nacionais atuarão no sentido de integrar o interesse da classe que representam com interesses mais gerais, por causa da existência interna de um "inimigo" que é em si mesmo geral, em alusão ao vírus. Acredita Badiou que concessões serão efetivadas pela 
conjuntura estabelecida durante a pandemia, mas o sentido dessas se direciona para a permanência da ordem social estabelecida.

Do mesmo modo, Žižek (2020, p. 58), ao tratar do Estado como ente provido de materialidade de ação para contornar o problema, entende que cabe ao Estado ampliar ações para a população. Para o filósofo esloveno, diante da pandemia se impulsionam novas formas de solidariedade local e global, "tornando mais clara a necessidade de controle sobre o próprio poder. As pessoas têm razão em manter o Estado como poder responsável: você tem o poder, agora nos mostre o que você pode fazer!" (ŽlŽEK, 2020, p. 58).

Assim, argumenta Žižek (2020, p. 53) que "a disseminação contínua da Covid-19 também desencadeou uma ampliação da vasta epidemia de vírus ideológicos que estavam adormecidos em nossas sociedades: notícias falsas, paranóicas teorias da conspiração, explosões de racismo". Além dessas questões, o estado de funcionamento “ideal” nos termos do capital financeiro, que no âmbito comunicacional midiático tem imposto a necessidade de "volta à vida normal".

Žižek (2020, p. 53) indica que talvez uma benéfica ideologia se propague e contamine muitos diante do contexto atual, "o vírus do pensamento de uma sociedade alternativa, uma sociedade além do Estado-nação, uma sociedade que se atualiza sob as formas de solidariedade e cooperação global".

Entendemos, a partir das colocações dos autores, que pensar a questão pandêmica está intrinsecamente ligado à compreensão de arranjos e percursos próprios do contexto em que estamos inseridos. No caso brasileiro, temos visto uma série de conflitos na ordem dos interesses daqueles que controlam o capitalismo no país, disputas entre grupos políticos que não só lidam com o estado de coisas provocado pela disseminação da Covid-19, mas lutam por um retorno integral da ordem classista que enseja a aceleração no processo de revogar direitos arduamente conquistados. 
O fato é que uma transformação efetiva e estrutural de nosso modo de vida é articulada em diversos campos; na arena do jogo político, a classe hegemônica encontrase em conflito direto com os grupos contra-hegemônicos.

A crítica às ideias falsas e ao falseamento da realidade ganha fôlego neste momento em que é exercido o combate às consciências ilusórias, nos levando ao que Marx e Engels definiram em relação à compreensão e desmitificação da ideologia, que é o entendimento do lugar do homem no mundo, sua objetividade e subjetividade. De modo mais contundente, quando as disputas políticas ganham corpo, rompe-se com a teleologia e se incorporam as contradições; assim a dialética explicita o campo da compreensão e das mudanças necessárias para confrontar o estado de desigualdade naturalizado em sociedades como a nossa.

Talvez a radicalização de ações contra-hegemônicas seja hoje a questão mais utópica que possamos pensar no momento, apesar de estarmos notadamente e de modo explícito em um Estado que radicaliza ações antidemocráticas, inconstitucionais e “passando a boiada”, como afirmou o ministro Ricardo Salles, responsável (?) pelo Meio Ambiente, quando na reunião ministerial de 22 de abril de 2020, disse que o momento da grande atenção à pandemia seria ideal para reformas infralegais de desregulamentação e simplificação em diversos ministérios no sentido de esses grupos que estão controlando o Estado brasileiro aproveitarem a pandemia para instaurar e incrementar o caos da guerra viral $(\mathrm{G} 1,2020)$. É utópico (no sentido de idealista) imaginar que as estruturas de poder historicamente autoritárias e reacionárias possam dar lugar a transformações em prol de solidariedade e melhorias ao trabalhador.

No Brasil, durante a pandemia da Covid-19 em 2020, e sob o governo de ultradireita de Jair Bolsonaro, observamos clara atuação de Lawfare e lobbies que atuam, assim como Salles, pela perspectiva de fazer reformas em prol do mercado, denotando a aposta pela mortandade. Ou seja, é um Estado que visa enxugar os direitos sociais, muitas vezes suprimindo-os, e concentrando desmedidamente controles sociais, econômicos, políticos etc. em corporações privadas. É acrítico conceber algo positivo de um governo 
que existe para implementar de forma radicalizada as reformas de Estado em benefício do neoliberalismo.

Terezinha Santos (2012) nos desvela a reconfiguração do Estado brasileiro nos anos de 1990 e sua ampla adesão à lógica de mercado, ou seja, a submissão aos ditames do Consenso de Washington (privatizações, abertura da economia, desregulamentação e rígido controle da inflação e do déficit público, sobretudo, faziam parte do receituário). Para a autora, há transferência de uma responsabilidade/solidariedade social politizada, para a lógica dos ideólogos da terceirização, de que Organizações Não Governamentais têm melhores condições de amalgamar e resolver as demandas sociais e os recursos públicos. Assim, a autora considera que a ideologia atrelada ao modelo gerencial do neoliberalismo "gera o empobrecimento do campo político, uma das poucas possibilidades para a luta por melhores condições e transformação da sociedade, porque aos benfeitores só se agradece civilizadamente, sem necessidade do embate, da luta, gerando uma figura passiva e não um cidadão participativo" (SANTOS, 2012, p. 108).

Dessa forma, a vontade de mudar, de pensar utopicamente (no sentido crítico defendido por Bloch), apenas se efetiva diante de uma emancipação das estruturas que escamoteiam ou que, por quaisquer meios, criam engodos sobre a realidade. Será que estamos preparados para resgatar as contradições e lidar com elas? A complexa relação, quase que doentia, de repulsa ao passado, não nos revela uma sociedade incapaz de mover-se para alguma mudança qualitativa, expressiva e ética? Será que as utopias estão alicerçadas de modo denso em alguma capacidade de pensar o passado, suas complexidades, contextos e atores? Há objetivamente a intenção de um mundo melhor? Será que há experiências do passado que nos servem para aprendizado sobre o que não fazer e podemos usar isso? Será que nos sentimentos utópicos, que fervilham neste momento, há espaço para compreensão da gama de processos que precisam ser assimilados para que sejam efetivamente transformados?

Em uma sociedade que desconhece pluralidade no campo decisório e espaços de representatividade, será utópico (no sentido idealista mais pleno) pensar que atuaremos numa frente ampla propositiva para mudar a realidade. Enquanto se divulga nas mídias a 
crise pandêmica, as dificuldades dos mercados, alguns crimes políticos, o levante étnico (não o primeiro no longo percurso histórico de luta, resistência e resiliência para sobreviver e mudar a realidade imposta desde o colonialismo) e a emergência de práticas de contenção das doenças, neste ínterim de discussões sérias também se ampliam projetos que destituem dos indivíduos, de comunidades e grupos sociais complexos o direito à dignidade, sobrevivência, educação, saúde.

Será que na seara das ideologias, o campo de mudanças estruturais gerais está sendo levado para o debate de apenas algumas, apesar de importantes, mazelas de nossa sociedade? Será que não estamos sendo mais uma vez instrumentalizados ou orientados a seguir o caminho do "devagar e sempre"? Será que cairemos no golpe da representação, por si mesmo pró-forma? Talvez Freud explique, visto ser especialista na compreensão das fragilidades das razões e das desrazões dos seres humanos no campo do poder. A psicopatologia da vida cotidiana é a tradução dos enredos que projetamos nas nossas percepções de mundo, teias carregadas de distorções, de aspectos ideológicos que permeiam nossa relação com o conhecimento da realidade e de nós mesmos.

A perpetuação de mecanismos de dominação está no campo ideológico, que é cultural. Para o pai da psicanálise, há constante manutenção do patrimônio mental da civilização, e as normativas sociais são implementadas por medidas de coerção, entre outras, que têm manifesto objetivo de reconciliar os homens com seu destino material e sua consequente recompensa do sacrifício ao trabalho opressivo a que fomos sujeitos historicamente, e assim aculturados (FREUD, 1969).

Mas compreendemos o que Gramsci apontava ao analisar que o socialismo não pode ser visto ou defendido apenas sob a perspectiva econômica, já que a política e a economia são instrumentos fundamentais para que possamos entender o mundo e atuar sobre a realidade. O pensador sardo, que passou anos em cárcere e produziu uma das mais expressivas obras para compreensão dos aspectos históricos e políticos de seu tempo, a partir do estudo da ascensão burguesa no campo político, compreende que a escolha de elementos fomentadores de certa "ordem" foram fundamentais para 
ascensão e manutenção desses grupos no poder, como a lógica das instituições de direito.

Como meios de assegurar o acesso a normativas que oferecessem algum modo de equilíbrio nas relações sociais, criou-se, mesmo diante de contendas diversas, espaço de alguma representatividade das classes subalternas. Para o autor, mais do que nos darmos conta das estruturas econômicas e dos desequilíbrios advindos delas, precisamos ampliar o palco de discussão e a percepção da realidade histórica concreta, e isso se dá através do entendimento dos variados cenários políticos que permeiam a sociedade. A prática e a atuação política, no entanto, envolvem mais que o poder; o fazer política é mais que isso. Ao compreender o mundo, o transformamos, pois modificamos nossa relação e atuação nele. Hobsbawm (2011, p. 308) capta no pensamento gramsciano o sentido de mudança, o despertar político. O interesse pela realidade é basilar para suscitar instituições políticas vigorosas; ao se entenderem seres políticos e históricos, os indivíduos compreendem as contradições da sociedade.

Bianchi (2007), em pesquisa sobre as bases do conceito de hegemonia gramsciano, indica que o pensador, a fim de compreender como ela é construída nos espaços de disputa e dominação, parte do entendimento de que a supremacia de um grupo social se manifesta de duas maneiras, como ‘domínio’ e como ‘direção intelectual e moral'. A partir disso, desenha o conceito de hegemonia em estreita relação a temas e contextos históricos e à luz de uma clara reflexão dos mecanismos de direção e dominação numa relação dialética, em que esse par de engrenagens compõe a hegemonia, bem como a relação entre estrutura (economia) e superestrutura (instâncias políticas, ideológicas e jurídicas). Essa é mediada pelo Estado integral, em que há uma prevalência do consenso, entendido como persuasão/convencimento, nas instituições denominadas privadas da sociedade civil e a força predominante na sociedade política, ou Estado em sentido restrito.

Ou seja, nas instituições de hegemonia há uma certa mescla de elementos que integram a concepção de ideologia. Para Gramsci, se institui tanto como sistema de ideias com dimensões articuladas no campo do inconsciente quanto no campo institucional das 
relações. Para o pensador italiano, é "prática social vivida” e passa por processos históricos, produzindo a cada época padrões de consenso; a ideologia é a forma que carrega conteúdo ou materialidades para exprimir e concentrar as dominações, visto que o processo hegemônico é dinâmico (EAGLEATON, 1997).

Mészáros (2004), por sua vez, acredita que há disputas sempre assimétricas das ideologias, que afetam a totalidade da consciência social e levam as pessoas a endossar valores e práticas políticas contrários aos seus interesses.

as ideologias críticas que tentam negar a ordem estabelecida não podem mistificar seus adversários pela simples razão de que não têm nada a oferecer — por meio de suborno e de recompensas pela acomodação àqueles que já estão bem estabelecidos em posição de comando, conscientes de seus interesses imediatos tangíveis. Por isso, o poder da mistificação sobre o adversário é um privilégio da ideologia dominante (MÉSZÁROS, 2004, p. 301).

Compreendemos que este momento pandêmico nos revela um caos sistêmico e uma série de disputas que se acirram na medida dos efeitos nocivos pré e póspandêmicos. Para Santos (2020), uma crise mundial se aprofunda, assim como o neoliberalismo se reorganiza para manter a hegemonia dominante. Observamos diversas formas de resistência pulsantes, assim como modos de recrudescimento de ações contra as classes trabalhadoras.

Dessa maneira, temos um panorama que se desenha na lógica de ampliação de disputa nos campos hegemônicos. Um exemplo claro é a educação.

Os efeitos da pandemia na educação têm evidenciado e até mesmo exacerbado contradições e assimetrias próprias de sociedades desiguais, como a brasileira. Isso se reflete na dificuldade de acesso, condições precárias e, principalmente, falta de equipamentos e infraestrutura da maioria de estudantes pobres e miseráveis, e que parcela significativa de docentes compartilha. Em termos de relações laborais, docentes se defrontaram com a agudização do aviltamento de suas condições e o arrocho salarial 
intenso chancelado por medidas governamentais, que repercutem também entre professores na educação privada. Não obstante, a educação pode ser espaço democrático de discussão de ideias e mudanças, sem deixar de apresentar as carências e fragilidades construídas pelo descaso histórico de governos descomprometidos com o aperfeiçoamento científico e pedagógico.

Os enaltecidos e supervalorizados supostos méritos do ensino a distância, tidos muitas vezes como "técnica neutra e objetiva", propícia para oferecer oportunidades e concretizar a educação por vias remotas, se defronta com a realidade adversa e distante do idílico mundo vendido pelo marketing do setor, pródigo em vender panaceias e outras imposturas. Sem mencionar o fato de que as questões centrais da Educação não são passíveis de soluções no campo das TIs (Tecnologias da Informação) (CASTELLS, 2015; PITASSI; LEITÃO, 2002).

Segundo Mandela (2003), "a educação é a arma mais poderosa que você pode usar para mudar o mundo", pois essa dimensão da vida social tem imbricada disputas pela configuração da realidade. Na Educação, o neoliberalismo tem agendas próprias além da privatização das escolas públicas, pois exerce funções de controle e censórias que visam mitigar e esterilizar os ímpetos por democracia e direitos sociais que possam emanar do convívio e de debates no ambiente escolar. O objetivo precípuo é de retirar entraves que possam interferir nas novas maneiras de acumular capital na fase financeira desse sistema político-econômico.

O trabalho remoto vem reorganizar novas formas de precarização e usos do espaço público como espaço de entes privados. Para Žižek (2020), a subordinação da classe trabalhadora ao capital sujeita ainda mais os trabalhadores à lógica do sistema capitalista, já que não bastam as condições do trabalho remoto, que em si são desiguais, mas há ainda o trabalho que não pode ser exercido remotamente, notadamente ampliando os danos de saúde e precarização. Em ambos os casos, o autor atenta-nos para as questões objetivas, que são obviamente as condições de trabalho, o excessivo número de horas para o atendimento de novas demandas e recursos materiais, por exemplo, como também discorre sobre as questões subjetivas advindas de práticas que transferem 
ao trabalhador o papel de "algoz" de si mesmo, realizando tarefas no intuito de ter sobrevida no emprego, essencialmente "realizando a função do capitalista" para assegurar o sucesso da empresa "sob a sua responsabilidade" (ŽlŽEK, 2020, p. 48).

Daniele Linhart (2016) compreende esse fenômeno em seu campo de estudo, a sociologia do trabalho, e acredita que o trabalho contemporâneo é moldado sob o prisma da subjetividade nas relações e organização do mundo do trabalho. Desde a ideia de individualização, meritocracia, a necessidade do trabalho para a sobrevivência como também para a socialização do indivíduo e o sentimento de pertencimento. Para ela, há elevado incentivo ideológico à autonomia do trabalho na década de 1990, e tem-se um crescimento significativo do trabalho informal.

Daí surge a ideia do "trabalhador indivíduo" capaz de organizar, administrar e desenvolver uma lógica de atendimento de metas e comportamentos estandardizados que visam atender ao patronato via o próprio trabalhador, sob o modelo de coerção permanente, instabilidade econômica, estado de mudanças contínuas no dia a dia do trabalho e nas legislações a respeito. Assevera a autora que a suposta "autonomia" do trabalho "conseguiu introduzir uma variante deformada e inquietante desse modelo, uma declinação aberrante e fonte de mal-estar e de desequilíbrios" (LINHART, 2011, p. 157).

Ademais, a pandemia reverberou intensa e profundamente no cotidiano de bilhões de pessoas, alterando hábitos, criando fases de adaptação e intensificando os contatos virtuais, nos contextos em que eles eram possíveis. Como o convívio social presencial se tornou veículo de contágio e propagação, nos diferentes setores as atividades foram suspensas integralmente ou se verificaram de forma remota. $\mathrm{Na}$ educação, acenou-se com o recurso do ensino a distância e de outras modalidades para enfrentar a situação inusual, que ora perdura no início de 2021. Verificou-se, porém, o que já se sabia há tempos: em sociedades desiguais, a participação não poderia se dar nas mesmas condições. Um conjunto de precarizações foi arremessada à luz do dia, entre as quais, a baixa participação nas atividades escolares das camadas menos favorecidas em 
decorrência de falta ou insuficiência de infraestrutura mínima1; o prolongamento das horas de trabalho de docentes e outras mazelas reinantes no dia a dia de sociedades assimétricas, mas escamoteados por verborragias "patrióticas" inócuas ou "pedagogias" de autoajuda, igualmente inúteis.

O momento, no entanto, é de euforia para corporações de educação digital. Tanto no campo dos conteúdos, quanto na tecnologia de suas plataformas, atuam amplamente no mercado privado e só encontraram o gargalo nos serviços e na precária qualidade da internet em muitos lugares. Mas, majoritariamente, a falta de operacionalidade do sistema de ensino remoto estava no serviço da educação pública, em que parte significativa de seus alunos não possui meios próprios adequados ao uso de tecnologias do âmbito. Diante da necessidade real em atender aos cidadãos menos privilegiados, entidades descomprometidas com distribuição de renda ou melhorias socioeconômicas de fato, apresentam-se como supostas benfeitoras, é o caso, por exemplo, da Fundação Lemann e grupos como o Todos pela Educação (TPE), que retoricamente se dizem empenhados em articular meios de implementar marcos regulatórios para que soluções de educação digital cheguem às classes ou grupos despossuídos de tais meios.

Tomamos como exemplo a denúncia da entidade Campanha Nacional pelo Direito à Educação (2020) sobre o webnário organizado em abril de 2020, pelo TPE, em que se discutiu a "urgência" da regulação da questão EaD no ensino público. Participaram somente o TPE, Banco Mundial e o Conselho Nacional de Educação (CNE), e foram excluídas outras instâncias e entes que atuam seriamente no setor como a União Nacional dos Conselhos Municipais de Educação (UNCME), os sindicatos dos profissionais da educação, as entidades estudantis, outros atores da sociedade civil e as associações científicas ligadas à educação. Também vemos que em março de 2020, no começo da pandemia da Covid-19, a Fundação Lemann (2020) e Imaginable Futures já criavam um projeto piloto com escolas públicas de diversas regiões do país no sentido de auxiliá-las durante a pandemia a planejarem ações para viabilizar o ensino remoto com tecnologias

\footnotetext{
1 Isso se traduz na participação das atividades EaD entre $24 \%$ a $27 \%$ dos estudantes, do universo de 3,5 milhões de estudantes da rede pública de São Paulo, o estado mais rico do país, de acordo com levantamento referente ao mês de maio da Apeoesp (2020, apud REDE BRASIL ATUAL, 2020).
} 
educacionais, o que denota, na nossa perspectiva, um modo de sobrepor interesses corporativos às reais demandas sociais.

Entendemos que o momento pandêmico acentua as intensas transformações e reorganizações dos papéis e da atuação no cenário político e econômico, toma formas cada vez mais assimétricas e evidencia uma lógica em que o "mercado" se supõe superior e impõe essa construção ideológica a qualquer outra forma de ordenação social. O golpe de Estado de 2016 (BEVILACQUA SOBRINHO, 2016; MIGUEL, 2018) demonstrou o desprezo das oligarquias brasileiras pelos acordos de diferentes classes formalizados na Carta Constitucional de 1988.

A característica antissocial, antipopular e antinacional das elites endinheiradas demonstrou de maneira insofismável não só o desapreço pela democracia liberal burguesa, em que pese todas as suas limitações, mas a decisão interna e externa do grande capital em impor sem limites as determinações do poderio e jugo estadunidense, atropelando regras básicas de convivência simbólicas e físicas, inclusive, para obedecer ao atendimento de imperativos geopolíticos dos EUA. Nessa manobra golpista, revogaram-se direitos trabalhistas, previdenciários, sociais e, fundamentalmente, a soberania do país, com a entrega desabrida do patrimônio nacional aos estrangeiros como parte do pacto de lesa-pátria, como, por exemplo, os acordos ilegais da força tarefa da Lava-Jato com o FBI (VIANA; NEVES, 2020).

A partir do conjunto de transformações advindas do projeto neoliberal no Brasil, que desde 1995, com a reforma do Estado brasileiro, estimula mudanças no sistema produtivo no sentido de garantir maior possibilidade de ampliação de capital flexível em diversos âmbitos, desde o setor produtivo, mas também financeiro e nos negócios do Estado, as empresas mercantis do setor de educação têm empreendido seu espaço de atuação e influência, sempre ávidas por sugar fundos públicos. Cumprem seu papel nesse (des)arranjo, buscando privatizar o ensino em todos os níveis e se apropriar de investimentos históricos que, por décadas, edificaram universidades com sólida reputação devido à qualidade de seus pesquisadores e professores. 
Alargando a compreensão dessa lógica de mercado na educação, consideramos os estudos de Ball (2006, p. 13) quanto às privatizações e à precarização na esfera da educação pública, que se dão no sentido de impor interesses privados nos espaços de regulação pública, no qual "há imposição e o cultivo da performatividade na educação e no setor público, somados à importação e disseminação do gerencialismo e [...] cultura de controle do capital privado". Ball (2014), através de seus estudos sobre as redes que demonstram expressivo grau de interesse na educação, indica conglomerados globais, fundações ligadas ao terceiro setor e entidades internacionais (Banco Mundial, OCDE, entre outras). Entendemos que diante da Covid-19 esses setores alargam sua atuação propalando soluções na educação via Tls, como vemos em Tam e El- Azar (2020).

Ao contrário das narrativas que endeusam as possibilidades das TICs - Tecnologia da Informação e Comunicação, mormente em situações impostas pela Covid-19, não podemos deixar de atentar para os aspectos ideológicos da sociedade da informação. Como adverte Castells, “a manipulação ideológica que caracteriza a maior parte dos discursos sobre a revolução da tecnologia da informação não deveria levar-nos a cometer o erro de subestimar sua importância verdadeiramente fundamental” (CASTELLS, 2000, p. 50).

Interferir na realidade (BRECHT, 1967), todavia, é responsabilidade de todos os que têm comprometimento de fato com as questões pedagógicas e de como elas podem formar cidadãos aptos a decidir os rumos pessoais e dos lugares em que estejam, participando dos debates de interesse coletivo para engendrar intervenções demandadas pela maioria, e não as de oligopólios e suas influências deletérias.

Parte dos discursos neste momento pandêmico, versa sobre a ampliação das tecnologias educacionais para inovação e soluções no atendimento ao público educacional, como as possibilidades de melhoria da qualidade da educação, tais como propagam diversas empresas do ramo EaD que têm crescido no mercado. A título de exemplificação, a Liga Insights (2020), em panorama das startups brasileiras na Educação, feito em parceria de Derraik \& Menezes, IGC Partners, Ambev e Cargill, indica que existem 287 startups atuando em 18 categorias diversas, desde financiamento, tutoria, produção 
de conteúdo e desenvolvimento de plataformas. Isso sem levarmos em conta as enormes Google, Apple, Facebook, Amazon e Microsoft, que estão na mesma rede de disputas em parceria com instituições de grande porte ligadas ao terceiro setor e que também atuam no setor público educacional.

Para Mészáros (2008), é extremamente claro que na educação escolar existe um reforço de uma internalização dos modos do sistema capitalista; não há espaço para melhorar algo sem o aspecto democrático do direito à participação decisória, a escola reproduz as intenções do sistema capitalista e programas de governo. Portanto, se deslocarmos essa lógica para a educação via sistemas tecnológicos de informação, temos de observar que a possibilidade de atuação do mercado privado sobre a educação ampliase exponencialmente, nos levando a considerar maior penetração de arranjos que direcionam a educação a interesses privados e não democráticos.

No entanto, os profissionais, pais, estudantes e entidades em prol da educação de qualidade e gratuita se colocam veementemente contra as imposições desse modelo de escola, contra os riscos sociais, econômicos e psicológicos que essas ações arbitrárias carregam. Vemos através de Webnários uma complexa rede organizada para fomentar debates e ações em torno da participação democrática nas decisões sobre a educação brasileira. Também entidades, organizações acadêmicas e sindicatos têm levantado significativos esforços para denúncia e mobilização contra os engodos dessa lógica de mercantilização da educação e seus riscos para os direitos educacionais tanto para as crianças e jovens, quanto para os profissionais do setor. Podemos aqui exemplificar a CNTE-Confederação Nacional de Trabalhadores na Educação, a Rede Escola Pública e Universidade (REPU) e o Grupo Escola Pública e Democrática (GEPUD).

Portanto, esses embates são fundamentais, visto que estamos diante de uma possibilidade bem próxima da obra ficcional 1984 (George Orwell) ou Fahrenheit 451 (Ray Bradbury): uma sociedade tornada completamente explorável. Klein (2020) delineia o percurso histórico dos grupos de vigilância e controle absoluto via tecnologia que se constrói nos Estados Unidos, que inclui a efetiva participação do departamento de defesa estadunidense. A ativista indica, através de levantamentos de relatórios, entrevistas e 
dados de pareceres e especialistas no setor de segurança e democracia digital, que caminhamos para um processo sem volta no que tange às violações das liberdades individuais em torno do direito à privacidade e ao direito a decisões seguras. Para ela,

É um futuro que alega ser executado por 'inteligência artificial', mas na verdade é mantido em funcionamento por dezenas de milhões de trabalhadores anônimos escondidos em armazéns, centros de dados e moderação de conteúdos, fábricas escravizantes de eletrônicos, minas de lítio, fazendas industriais, frigoríficos e prisões, onde são deixados desprotegidos de doenças e hiperexploração. É um futuro em que todos os nossos movimentos, todas as nossas palavras, todos os nossos relacionamentos são localizáveis, rastreáveis e passíveis de terem seus dados minados por colaborações inéditas entre os governos e as empresas gigantes de tecnologia (KLEIN, 2020, sem paginação).

Na realidade brasileira, a título de exemplo, temos uma agressiva abordagem do governo estadunidense para a aquisição do seu modelo de tecnologia $5 \mathrm{G}$, em detrimento do Huawei, companhia de tecnologia da China, país com o qual os EUA têm ampla disputa geopolítica. O governo federal brasileiro, de extrema-direita, inclina-se à demanda dos Estados Unidos (BENITES, 2020), nesta e em muitas outras questões (PAULANI, 2018).

Ocorre que há uma gama de instrumentalizações sobre o uso de tecnologias digitais na esfera privada e as regulações constitucionais de direito ou não de um estado de vigilância no cotidiano cibernético dos indivíduos. Acontecem hoje diversas discussões sobre os marcos regulatórios no sistema de acesso aos celulares de indivíduos no país. Há controvérsias sobre meios de combate à doença Covid-19 produzirem invasão de privacidade, notadamente o uso de rastreamento a partir do acesso a dados das operadoras de celulares para identificar aglomerações de pessoas em todo o país (SCHREIBER, 2020). A reportagem da BBC (MAGENTA, 2020) aponta que especialistas do campo jurídico de segurança de dados indicam que "a medida, adotada em outros países, é defendida como uma forma de conter o avanço do novo coronavírus. [...] no entanto, alertam que esse tipo de vigilância não pode levar à violação do direito à privacidade assegurado na legislação". 
No governo de Jair Bolsonaro vemos que, em se tratando de violações ao direito constitucional ou intransigências no campo democrático, não é duvidoso pensar que a adoção de medidas dos referidos controles de deslocamentos populacionais possa ser aproveitada como porta de entrada para uma estrutura de vigilância mais organizada, não apenas no campo nacional, mas principalmente para proporcionar uma abertura subalterna de acesso às grandes corporações e a entes externos, como é o caso estadunidense, que se reorganiza em torno de entidades privadas com meios diversificados e complexos para aprofundar instrumentos de controle e viabilizar integralmente o capitalismo de vigilância [Surveillance Capitalism] (ZUBOFF, 2019), uma sociedade distópica submetida ao policiamento cada vez mais estrito, com o uso em larga escala de big data para vender predição comportamental em massa.

Estamos diante de um processo de afirmação dos preceitos do corpo hegemônico dominante, que se organiza e forma redes de sustentação da manutenção de seus intentos. Gramsci (2002), ao estabelecer análise da composição do Estado e do Direito, conforme vemos no Caderno 9, dos Cadernos do Cárcere, no parágrafo destinado à compreensão do "Estado e da concessão de direito", considera que na educação, em sentido amplo, reside a capacidade de manutenção da hegemonia da classe burguesa e seus interesses. Por isso, se refere ao papel educador do Estado. Nesse processo, a classe dominante tende a assimilar vários grupos sociais, mantendo uma direção moral, política e dos direitos, dessa forma há uma lógica de controle e modos de assegurar a hegemonia dominante.

Por conseguinte, há complementariedade e sintonia de interesses entre o governo dos EUA e os conglomerados Google, Alphabet (controladora da Google), a Amazon etc., que exigem vultosos investimentos públicos direcionados no sentido de subsidiar suas empresas privadas para financiar pesquisas em IA - Inteligência Artificial e infraestrutura que habilitem tecnologias $5 \mathrm{G}$ e associadas. As grandes corporações mencionadas empreendem meios de ajustar seu domínio a um novo ordenamento jurídico imperial estadunidense, no que tange ao direito de usos de dados, para tentar superar a defasagem científico-tecnológica em relação aos avanços evidentes verificados na China 
(KLEIN, 2020). Esses marcos regulatórios são muito expressivos em sociedades como a brasileira, que possuem alinhamento ideológico e dos setores produtivos internos muito inclinados a seguirem a mesma lógica. Ademais, na trama das relações entre os entes econômicos e hegemônicos politicamente em nosso país, há intenso desejo por seguir tais direcionamentos do "Grande Irmão".

Para Gramsci, a hegemonia dos grupos subalternos é um meio de superar os instrumentos e instituições de dominação do mundo capitalista, que em sua análise se reinventará e se reorganizará, pois "todo Estado tende a criar e a manter um certo tipo de civilização e de cidadão, tende a fazer desaparecer certos costumes e a difundir outros" (GRAMSCI, 2002, p. 28). Assim, trazemos questões para o debate: será que as utopias de mudança estão preparadas para compreender que o mundo do trabalho e a composição de classes subalternas é ainda o problema a ser resolvido? Será que as concepções acerca da realidade estão claras o suficiente para que as utopias sejam críticas e apostem em soluções assertivas? A concepção de mundo anacrônica nos leva a respostas incongruentes, pois nosso tempo presente é resultado de intenções do passado e de intenções atuais. Nossa elaboração intelectual é capaz de passar do estágio de compreensão para o processo de atuação em termos políticos? Há possibilidades de vários grupos contra-hegemônicos coadunarem-se para além das suas demandas imediatas e pensarmos num futuro distinto?

Para que a utopia nasça, segundo Bauman (2017), duas condições são necessárias: a extrema inconformidade com o funcionamento do mundo e a existência de uma confiança no potencial humano à altura da tarefa de reformar o mundo. Teremos a capacidade de confiar no potencial humano para que a utopia renasça e seja crítica?

\section{Referências}

BADIOU, Alain. Sobre a situação epidêmica. In: DAVIS, Mike et al. Coronavírus e a luta de classes. Brasil: Terra sem Amos, 2020. 
BALL, Stephen J. Educação Global S.A: Novas redes políticas e o imaginário neoliberal. Ponta Grossa, PR: UEPG, 2014.

BALL, Stephen J. Sociologia das políticas educacionais e pesquisa crítico social: uma revisão pessoal das políticas educacionais e da pesquisa em política educacional. Currículo sem Fronteiras, [S.I.], v. 6, n. 2, p.10-32, jul./dez. 2006. Disponível em: http://curriculosemfronteiras.org/vol6isszarticles/ball.pdf. Acesso em: 20 abr. 2020.

BAUMAN, Zygmunt. Bauman: Para que a utopia renasça é preciso confiar no potencial humano. Entrevista cedida a [Dennis Oliveira]. Revista Cult, [São Paulo], og jan. 2017. Disponível em: https://revistacult.uol.com.br/home/entrevista-zygmunt-bauman. Acesso em 29 jun. 2020.

BENITES, Afonso. Leilão do $5 \mathrm{G}$ no Brasil é novo capítulo da guerra fria do século XXI entre China e Estados Unidos. El País, Brasília, 22 jul. 2020. Disponível em: https://brasil.elpais.com/brasil/2020-07-22/leilao-do-5g-no-brasil-e-novo-capitulo-daguerra-fria-do-seculo-xxi-entre-china-e-estados-unidos.html. Acesso em: 01 out. 2020.

BENJAMIN, Walter. Teses sobre o conceito da história, 1940. Obras escolhidas: magia e técnica, arte e política: ensaios sobre literatura e história da cultura. São Paulo: Brasiliense, 1987. v. 1, p. 222-232.

BEVILACQUA SOBRINHO, Agenor. A Lente. São Bernardo do Campo: Cia. Fagulha, 2016.

BIANCHI, Álvaro. Estratégia do contratempo: notas para uma pesquisa sobre o conceito gramsciano de hegemonia. Cadernos Cemarx, São Paulo. n. 4, p. 9-39, 2007. Disponível em:

https://econtents.bc.unicamp.br/inpec/index.php/cemarx/article/download/10807/6069. Acesso em: 07 mar. 2020.

BLOCH, Ernst. O princípio esperança. Rio de Janeiro: Contraponto, 2005.

BRECHT, Bertolt. Teatro dialético: ensaios. Rio de Janeiro: Civilização Brasileira, 1967.

CAMPANHA NACIONAL PELO DIREITO À EDUCAÇÃO. Análises: não é hora de trabalharmos juntos? São Paulo, 09 abr. 2020. Disponível em: https://campanha.org.br/analises/fernando-cassio/nao-e-hora-de-trabalharmos-juntos. Acesso em: 12 jun. 2020.

CASTELLS, Manuel. A comunicação em rede está revitalizando a democracia. Entrevista cedida a [Malu Fontes]. Fronteiras do Pensamento, [S.I.], 11 mai. 2015. Disponível em: https://www.fronteiras.com/entrevistas/manuel-castells-a-comunicacao-em-rede-estarevitalizando-a-democracia. Acesso em: 09 jun. 2020. 
CASTELLS, Manuel. A era da informação: economia, sociedade e cultura. In: A Sociedade em rede. São Paulo: Paz e Terra, 2000. v.1.

CASTELLS, Manuel. Tempo de vírus. Unisinos - Adital, São Leopoldo, 27 mar. 2020. Disponível em: http://www.ihu.unisinos.br/78-noticias/597516-tempo-de-virus-artigo-demanuel-castells. Acesso em: 10 jun. 2020.

EAGLETON, Terry. Ideologia. São Paulo: Boitempo, 1997.

FREUD, Sigmund. O futuro de uma ilusão: O mal-estar na civilização e outros trabalhos: Volume XXI (1927-1931). Rio de Janeiro: Imago Editora, 1969.

FUNDAÇÃO LEMANN. Apoio às redes públicas de ensino: Fundação Lemann e Imaginable Futures ajudam redes públicas a planejarem ações para viabilizar o ensino remoto com tecnologias educacionais, [São Paulo], 31 mar. 2020. Disponível em: https://fundacaolemann.org.br/noticias/apoio-a-redes-publicas-de-ensino. Acesso em: 01 out. 2020.

G1. Ministro do Meio Ambiente defende passar 'a boiada' e 'mudar' regras enquanto atenção da mídia está voltada para a Covid-19, [S.I.], 22 mai. 2020. Disponível em: https://g1.globo.com/politica/noticia/2020/05/22/ministro-do-meio-ambiente-defendepassar-a-boiada-e-mudar-regramento-e-simplificar-normas.ghtml. Acesso em: 01 out. 2020.

GRAMSCI, Antonio. Cadernos do cárcere. Rio de Janeiro: Civilização Brasileira, 2002.

HIRATA, Helena. Gênero, classe e raça. Interseccionalidade e consubstancialidade das relações sociais. Tempo Social: Revista de sociologia da USP, São Paulo, v. 26, n. 1, p. 6173, 2014. Disponível em: https://www.scielo.br/pdf/ts/v26n1/05.pdf. Acesso em: 01 out. 2020.

HOBSBAWM, Eric. Como mudar o mundo: Marx e o marxismo, 1840-2011. São Paulo: Companhia das Letras, 2011.

KLEIN, Naomi. Coronavírus pode construir uma distopia tecnológica. Intercept, [Rio de Janeiro], 13 mai. 2020. Disponível em: https://theintercept.com/2020/05/13/coronavirusgovernador-nova-york-bilionarios-vigilancia. Acesso em: 2 jul. 2020.

LIGA INSIGTHS. As startups que atuam na educação: As startups brasileiras que estão mudando a educação no Brasil. Liga Insights EdTechs: as startups brasileiras que estão mudando a educação, [S.I.] 2020. Disponível em: https://insights.liga.ventures/estudoscompletos/edtechs-educacao. Acesso em: 17 jul. 2020. 
LINHART, Danièle. Danièle Linhart. Entrevista cedida a [Jussara Brito; Lúcia Rotenberg; Mary Yale Neves; Simone Oliveira]. Trab. educ. saúde (online), Rio de Janeiro, v. 9, n. 1, p. 149-160, mar./jun. 2011. Disponível em:

http://www.scielo.br/scielo.php?script=sci_arttext\&pid=S1981-

77462011000100011\&lng=en\&nrm=iso. Acesso em: 05 jan. 2020.

LINHART, Danièle. Linhart: a instituição da expropriação. Entrevista cedida a [Laurent Aucher; Fréderique Barnier]. Cadernos de Psicologia Social do Trabalho, v. 19, n. 1, p. 135141, 2016. Disponível em: www.revistas.usp.br/cpst/article/view/125908. Acesso em: 5 jan. 2020.

MAGENTA, Matheus. Coronavírus: governo brasileiro vai monitorar celulares para conter pandemia. BBC News Brasil, Londres, 3 abr. 2020. Disponível em:

https://www.bbc.com/portuguese/brasil-52154128. Acesso em: 1 jul. 2020.

MANDELA, Nelson. Iluminando seu caminho para um futuro melhor. Johannesburg: Instituto Nelson Mandela, 16 jul. 2003. Disponível

em: http://db.nelsonmandela.org/speeches/pub_view.asp?pg=item\&/temID=NMS909. Acesso em: 5 mar. 2020.

MARX, Karl. O 18 Brumário de Luís Bonaparte. In: Manuscritos econômico-filosóficos e outros textos escolhidos. 2. ed. São Paulo: Abril Cultural, 1978, p. 322-404. (Os

Pensadores).

MÉSZÁROS, Istvan. Educação para além do Capital. São Paulo: Boitempo, 2008.

MÉSZÁROS, István. O poder da ideologia. São Paulo: Boitempo, 2004.

MIGUEL, Luís Felipe. O colapso da democracia. São Paulo: Expressão Popular, 2018.

MST. Desde o início da pandemia, MST já doou 3400 toneladas de alimentos, [S.I.], 9 set. 2020. Disponível em: https://mst.org.br/2020/09/og/desde-o-inicio-da-pandemia-mst-jadoou-3400-toneladas-de-alimentos/. Acesso em: 01 out. 2020.

PAULANI, Leda. Economista Leda Paulani faz alerta sobre propostas econômicas de governo Bolsonaro. PODCAST: No jardim da política. [Locução de]: Marcelo Cruz [S. I.]: Brasil de Fato, 13 dez. 2018. Brasil de Fato. Podcast. Disponível em:

https://player.hstbr.net/radioagenciabdf/mobile.m3u. Acesso em: 27 set. 2020.

PERES, Ana Claúdia. Favelas contra o vírus: como as periferias vêm lidando com a pandemia de covid-19, em meio aos problemas cotidianos e diante da ausência de ações governamentais. Radis, Rio de Janeiro, 5 mai. 2020 Disponível em: 
https://radis.ensp.fiocruz.br/index.php/home/reportagem/favelas-contra-o-virus. Acesso em: 01 out. 2020.

PITASSI, Claudio; LEITÃO, Sergio Proença. Tecnologia de informação e mudança: uma abordagem crítica. Revista Administração de empresas, São Paulo, v. 42, n. 2, abr./jun. 2002. Disponível em: https://www.scielo.br/pdf/rae/v42n2/v42n2a07.pdf. Acesso em: 01 out. 2020.

REDE BRASIL ATUAL. Educação em SP. Frequência de alunos no ensino a distância de Doria não chega a 30\%. Rede Brasil Atual, [São Paulo], 29 mai. de 2020. Disponível em: https://www.redebrasilatual.com.br/educacao/2020/05/ensino-a-distancia-apeoesp-doria. Acesso em: 08 jun. 2020.

SANTOS, Boaventura de Sousa. A cruel pedagogia do vírus. Porto: Almedina, 2020.

SANTOS, Terezinha Fátima Andrade Monteiro dos. Administração da educação pública no Brasil: as parcerias público-privadas. Revista Exitus [Universidade Federal do Oeste do Pará/UFOPA], Santarém, v. 2, n. 1, p. 95-114, 2012. Disponível em: http://www.ufopa.edu.br/portaldeperiodicos/index.php/revistaexitus/article/view/70. Acesso em: 22 jan. 2020.

SCHREIBER, Mariana. Coronavírus: uso de dados de geolocalização contra a pandemia põe em risco sua privacidade? BBC News Brasil, Brasília, 21 abr. 2020. Disponível em: https://www.bbc.com/portuguese/brasil-52357879. Acesso em: 21 abr. 2020.

SUDRÉ, Lu. Para combater a "pandemia da fome”, MST já doou mais de 600 toneladas de alimentos. Brasil de Fato, São Paulo, 11 mai. 2020. Disponível em: https://www.brasildefato.com.br/2020/05/11/para-combater-a-pandemia-da-fomemst-ja-doou-mais-de-600-toneladas-de-alimentos. Acesso em: 1 jul. 2020.

TAM, Gloria; EL-AZAR, Diana. Três maneiras pelas quais a pandemia de coronavírus pode reformular a educação. Fórum Econômico Mundial e Minerva Project, [Cologny], 13 mar. 2020. Disponível em: 3 ways the coronavirus pandemic could reshape education. Acesso em: 10 jun. 2020.

VIANA, Natalia; NEVES, Rafael. O FBI e a Lava Jato. Pública; Intercept, [São Paulo], 01 jul. 2020. Disponível em: https://apublica.org/2020/07/o-fbi-e-a-lava-jato. Acesso em: 1 jul. 2020.

ŽIŽEK, Slavoj. PANDEMIC!: COVID-19 shakes the world. New York: OR Books, 2020.

ZUBOFF, Shoshana. The age of surveillance capitalism: the fight for a human future at the new frontier of power. New York: PublicAffairs, 2019. 
Recebido em: 04/07/2020

Aprovado em: 14/10/2020

Universidade do Estado de Santa Catarina - UDESC

Centro de Ciências Humanas e da Educação - FAED

PerCursos

Volume 21 - Número 47 - Ano 2020 revistapercursos@gmail.com 